
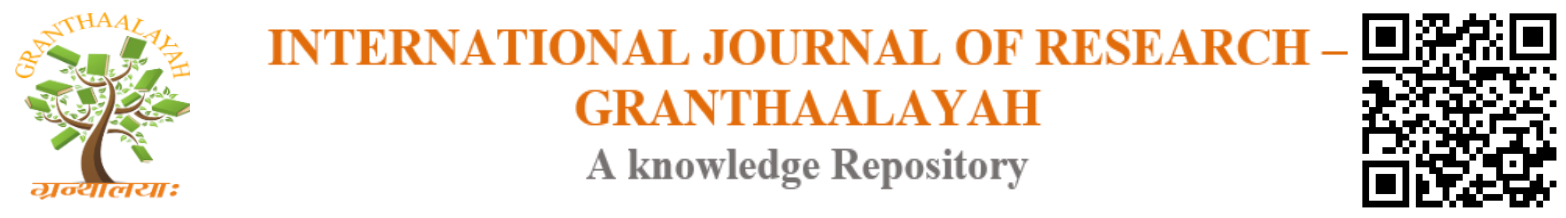

Social

\title{
ANALYSIS OF THE IMPORTANCE OF RESEARCH IN STUDENTS IN THE HEALTH AREA
}

\author{
Lcda. Alida Vallejo-Lopez ${ }^{1}$, Tibisay Rincón-Ríos ${ }^{2}$ \\ ${ }^{1}$ MSC, Faculty of Medical Sciences, University of Guayaquil Ecuador, Guayaquil Ecuador \\ ${ }^{2} \mathrm{Ph}$. D, Universidad Del Zulia-Venezuela, Ecuador
}

\begin{abstract}
Research is considered an activity aimed at obtaining significant findings that increase human knowledge and enrich science, thanks to it the world has changed generating progress, quality of life, health, innovation, hence the importance of promoting it in all educational levels. Teachers, who must implement the necessary strategies to improve the understanding of the issues contemplated in the syllable, guide the teaching-learning process in Higher Education Institutions. The objective of this article is to evaluate the knowledge of students in the area of health about research to analyze their research and scientific writing skills. Several factors influence the process that must be analyzed. To motivate students to carry out an investigation, curiosity and interest must be strengthened, also promoting social responsibility and commitment on various topics. Higher education institutions should give greater prominence to research and include it as a transversal axis along of all races.
\end{abstract}

Keywords: Teaching; Research; Student; Learning.

Cite This Article: Lcda. Alida Vallejo-Lopez, and Tibisay Rincón-Ríos. (2019). "ANALYSIS OF THE IMPORTANCE OF RESEARCH IN STUDENTS IN THE HEALTH AREA." International Journal of Research - Granthaalayah, 7(8), 245-249.

\section{Introduction}

Research in higher education is of great relevance today, during the teaching-learning process, for being a generator of new knowledge. Scientific research allows us to establish contact with reality so that we know it better, it also allows us to formulate new theories or modify existing ones.

Research is considered an activity aimed at obtaining significant findings that increase human knowledge and enrich science. It has the ability to favor the development of skills and the discovery of new facts, according to advances in technique, technology and thinking 1.

Undoubtedly, science is a matter of primary importance, to understand the world around us and the complex processes that occur in it. It is considered to have a strategic role in the development 
of a nation, both in the social, economic, and academic and health fields. Scientific development brings with it a cultural evolution for a better adaptation to the modern world.

Students, who enter the University and aspire to obtain a university degree, must develop research skills and for this, the teacher must promote the practice of research in all students, especially in the area of health. To carry out a scientific investigation the student has to learn that, it begins with a new idea, is structured as a hypothesis, which is accepted or rejected based on the results and culminates with the publication of the same (2)

Knowledge constitutes an intangible value for the human being; research must be a priority in university student life. Developing research skills allows to expand the field of knowledge. To respond to the requirements of higher education of the 21 st century, essential transformations are required to improve the educational-institutional model in order to respond effectively and with relevance to the demands of this new context that evolves day by day in the world current. (3) The relationship between teaching and research since the formation of modern European universities during the nineteenth century was conceptualized in two ways: the first, that of unity between teaching and research was the basis of the German university tradition; while the second, that of the separation of both processes, was the foundation of the Napoleonic University (4) From the precedents that have marked the evolution of universities, it is appropriate to refer to the new approach under which the third university mission (the other two are teaching and research) is increasingly interwoven: which consists of promote that new scientific knowledge, creative ideas and technologies generated within the university be put at the service of society, become new products or services valuable for the market and therefore, generate wealth and social welfare (5)

The objective of this article is to evaluate the knowledge of students in the area of health about research to analyze their research and scientific writing skills.

In the area of health, the medical career and related careers, have the obligation to know topics relevant to the area, therefore, teaching should be raised considering the most relevant content and research should be the component that complements that learning. The student should not be a database, but a restless being, capable of questioning and solving problems (6)

\section{Material and Method}

In the present work, it uses sources of consultation. Specialized journals such as Latindex, Scielo, Redalyc, and Review articles; it was considered to conduct a (survey) of the knowledge handled by students entering the Faculty of Medical Sciences at the University of Guayaquil in Ecuador. In the survey the degree of knowledge they have regarding the procedures and the parts of an investigation was considered, this survey was applied to a sample of 229 participants, chosen at random in the 2018-2019 leveling period, and based on the results, proceed to make the pertinent suggestions to improve the performance of students in the field of research.

\section{Results}

The university is the most suitable place to promote scientific activity, since it allows the cloister to keep in touch with the international flow of knowledge, through internationalization processes. 
This route allows enriching the productive systems, obtaining updated information and attracting financial resources, as well as establishing scientific projects of greater risk and potential profitability. (7)

Routine class activities can be enriched with activities that involve students; it is an added value to the established academic preparation. We need to improve our training, research, innovation, management and financing strategies and policies, eliminating ideological barriers and prejudices, taking advantage of the successful experiences and opportunities offered by new technologies. (8)

Among the many activities that can be carried out are several strategies, such as problem-based learning, ABP or ABI research-based learning, which can be applied in a group so that there is greater participation with the contributions of each member. Research-based learning (ABI) consists in the application of teaching and learning strategies that have the purpose of connecting research with teaching, which allows the partial or total connection of the student in an investigation based on scientific methods, under Teacher supervision. It refers to the design of the academic program where students have to make intellectual and practical connections between the content and the skills declared in the program, the research methods and the limits of the disciplines that compose it. (9)

Morales, P. (2010) in his article Research and educational innovation. He mentions Ernest Boyer's reflections in which he poses; it is useless to talk about improving the quality of teaching if the efforts of so many teachers to improve that quality are not recognized; If what counts is research and not effort and time, which means making students learn, it is not easy to motivate teachers to improve their teaching practices and think of possible much-needed innovations. The message alludes to that, in addition to recognizing the teacher for being a researcher, time must also be given to complement him with daily teaching activities, because it is the best way for students to learn, to improve research skills. (10)

In the field of the university educational community, research work will always be productive for all involved, and would be much more effective if implemented in curricula, throughout all university careers. It is urgent, then, to promote research as a resource for autonomous knowledge production, which depends not only on the creation of individual and group expertise and learning, but also on the efficient management and organization of research processes. (11)

Science goes hand in hand with research. The current trend in the world is to carry out research that is of public utility, especially when it comes to biomedical research. Institutions must support not only theoretical academic training, but training in the mainstays of research such as the concepts of basic sciences and statistics, a mechanism by which the relevance of a medical or scientific study is presented or established, regardless of the area in which it was developed. (12)

The information collected and analyzed from the articles shows that research is an essential tool that must be promoted and used by teachers to improve the learning process and their own curriculum.

From the results obtained it could be inferred that the students who participated in the study stated that they know the importance of investigating and allude that they know how to carry it out, 
however the majority indicated that they do not know the parts, nor the procedures, of an investigation, and They also recognize that they have not participated in research projects. They also indicate that they do not know how to carry out the problem statement (, 56.8\%) while high percentages $(71.9 \%)$ do not know what methodology should be used in the development of scientific research.

Almost the entire survey sample considers that it is important to learn to develop research (96.9\%) and participate in scientific journeys; in the same way, they believe that there should be support programs $(96.2 \%)$ aimed at students in order to acquire skills scientists to develop research papers

It is considered imperative to encourage research $(99.1 \%)$ so that students are prepared at the end of their professional careers and can develop their undergraduate thesis project

Almost the entire sample surveyed believes that research should be included as a transversal axis (SI 93\%) in the study programs.

\section{Conclusions}

- The development of scientific activity in higher education institutions should aim to improve academic performance and train competent professionals.

- The teacher must promote research because it is a strategy of great value to improve the learning process and develop scientific academic skills in students of university careers in the area of health.

- Students' interest in knowing more about research processes and their desire to participate in scientific exhibitions and events is recognized, which means that there is fertile ground to promote the development of a culture of researchers that generates new knowledge for the future of the students of the Faculty of Medical Sciences of the University of Guayaquil.

- Higher education institutions should give greater importance to research and include it as a transversal axis in all careers.

- This research is expected to motivate teachers to strengthen their teaching, with research carried out by students in the educational environment, of the Faculty of Medical Sciences of the University of Guayaquil in Ecuador, since undoubtedly research in all Health areas, contributes to the integrality, training of those who aspire to be health professionals.

\section{Final Reflection}

You can improve your knowledge by conducting research, and motivation is essential for this. It is important to involve students in exhibition activities and scientific conferences to generate a culture of researchers in the special area of health.

\section{References}

[1] Bijarro, Francisco (2007): "Desarrollo estratégico para la investigación científica", Cancún,<www.eumed.net/libros-gratis/2007c/306/306.zip> [15/08/2016].

[2] González Argotea Javier, Alexis Alejandro García-Rivero By Alberto Juan Dorta-Contreras Articulo Original Producción Científica Estudiantil en Revistas Médicas Cubanas 1995-2014. 
Universidad Nacional Autónoma de México, Facultad de Medicina Disponible en Internet 2 de marzo de 2016 Inv Ed. Med.2016;5(19):155---163

[3] GOMEZ, J. ; DIEGUEZ, P.; GOMEZ 2014 Motivando el interés por la investigación científica en estudiantes de educación media superior Congreso Iberoamericano de Ciencia, Tecnología, Innovación y Educación D ISBN: 978-84-7666-210-6 - Artículo 353 Buenos Aires Argentina Benemérita Universidad Autónoma de Puebla. México.

[4] Medina, D. E. M., \& Morales, N. A. (2014). Importancia del cambio generacional para el desarrollo de la ciencia y la tecnología en México. Hitos de ciencias económico administrativas, (50), 35-40.

[5] Molina, Ó. D. (2015). La transferencia de conocimiento científico y tecnológico: un reto que deben afrontar las universidades. Portal de la Ciencia, 8, 9-15.

[6] Norero V., Colomba. (2000). Medicina y ciencia: una relación indispensable. Revista chilena de pediatría, 71(2), 81-82. https://dx.doi.org/10.4067/S0370-41062000000200001 https://scielo.conicyt.cl/scielo.php?script=sci_arttext\&pid=S0370-41062000000200001

[7] Norero V., Colomba. (2000). Medicina y ciencia: una relación indispensable. Revista chilena de pediatría, 71(2), 81-82. https://dx.doi.org/10.4067/S0370-41062000000200001 https://scielo.conicyt.cl/scielo.php?script=sci_arttext\&pid=S0370-41062000000200001

[8] Ignacio Para Rodríguez-Santana El Modelo de Futuro de Gestión de la Salud, Propuestas Para Un Debate Editorial Visión Libros, 2012

[9] Tecnológico de Monterrey, 2014 http://sitios.itesm.mx/va/diie/tecnicasdidacticas/7_1.htm http://sitios.itesm.mx/va/dide2/tecnicas_didacticas/abi/qes.htm

[10] Morales, P. (2010). INVESTIGACIÓN E INNOVACIÓN EDUCATIVA. REICE. Revista Iberoamericana sobre Calidad, Eficacia y Cambio en Educación, 8 (2), 47-73.

[11] https://www.redalyc.org/pdf/551/55114080004.pdf

[12] Padrón, J. 2007. Tendencias Epistemológicas de la Investigación Científica en el Siglo XXI Cinta de Moebio 28: 1-28. www.moebio.uchile.cl/28/padron.html http://www.facso.uchile.cl/publicaciones/moebio/28/padron.pdf

[13] Ruiz Juan Carlos, M. (s.f.). LA INVESTIGACIÓN CIENTÍFICA EN EL ECUADOR. Mèdicina Crìtica, II (2). Obtenido de http://www.medicosecuador.com/medicina_critica/rev_vol2_num2/la_investigaciona.html

\footnotetext{
*Corresponding author.

E-mail address: olajiresola@yahoo.com
} 